\title{
Applying analysis of variance to determine stability of morphological and value for cultivation and use characteristics of Lactuca sativa var. longifolia L. variety of lettuce 'Skarb'
}

\author{
N. V. Leshchuk, Candidate of Agricultural Science \\ Ukrainian Institute for Plant Variety Examination \\ leschuk@sops.gov.ua
}

Purpose. Providing a scientific rationale for the practical application of analysis of variance elements to determine the range of morphological and value for cultivation and use (VCU) characteristics of Romaine lettuce 'Skarb' variety. Results. The Romaine lettuce 'Skarb' variety was identified by the type of display of quantitative (QN) identification characteristics. VCU characteristics of the var. longifolia L. varieties were determined and statistically processed. The author focused on practical application of histogram and variation curve of phenotype morphological characteristics when performing the uniformity test. The correlation between quantitative characteristics of lettuce leaf and head was observed when plant productivity was developing. Romaine lettuce yield value was verified statistically. Thresholds were established for the indices under study, confidence intervals were defined over the years of study. Conclusions. The use of Lewis stability factor (S.F. $=X_{\max } / X_{\min }$ ) allowed to establish the stability of each characteristic display. Practical application of the histogram and variation curve for determining code of display of quantitative morphological characters and the range of VCU characteristics of the Romaine lettuce 'Skarb' variety was scientifically grounded.

Keywords: Romaine lettuce, variety, identification, variation series, deviation, thresholds, characteristic stability.

Introduction. Identifying the cutting lettuce varieties by way of morphologically describing qualitative, quantitative and pseudo-qualitative characteristics enables obtaining a morphological coding for a phenotype, establishing correlation [thereof] with VCU characteristics of the plant generative organs. These are the quantitative characteristics of Romaine lettuce leaves and heads, in particular, leaf length and width, head height and diameter, the number of leaves, which require further improvement in terms of searching for confidence intervals and variation range thresholds for the purpose of histogramming and tracing the curve of morphological and VCU characteristics expression.

Studies of foreign and domestic scientists have been monitored as regards the identification of cutting lettuce varieties identification and cultivation for marketing and seed production purposes. That reveals a range of the technological measures and the enhanced techniques of manufacturing marketable commodities and seed, targeting chiefly leaf lettuce and head lettuce. Ukraine has Romaine lettuce among its minor vegetables. That limits its cultivation [1]. Such foreign breeding varieties as 'Veradarts', 'Paryzkyi zelenyi', Ballon are well-known in Ukraine. The above varieties of Romaine lettuce are only spread among private households, most of them without official listing. So far, a domestic breeding Romaine lettuce 'Sovskyi' variety is the only one to represent var. longifolia $\mathrm{L}$.
An extremely narrow assortment of Romaine lettuce currently provides no option for implementing the selection of high-performance adapted varieties for the conveying (ongoing) production meeting the demand for fresh vegetables grown in open field throughout early spring to autumn and winter season for all the ecological gradients. Examining distinctness of Romaine lettuce varieties breeding material as followed by further actual use of the analysis of variance to determine the range of Romaine lettuce candidate varieties morphological and VCU Characteristics, underpins Relevance of the study.

Aims and objectives of the study seek a validation for morphological description of quantitative characteristics as the Romaine lettuce 'Skarb' variety is being identified, disclosing actuals use for the histogram and variable curve of phenotype morphological characteristics as the uniformity test is being conducted, and displaying a correlation of phenotype with VCU indices of plant productivity.

Materials and methods. The field examination of distinctness of Lactuca sativa var. longifolia $\mathrm{L}$. varieties was being conducted at the plots of Maiak Testing Station under the Horticulture and Melon Cultivation Institute, NAAS (village of Kruty, Nizhyn district, Chernigiv region) during 2005 to 2007 . The design of field trials cultivating the cutting (Romaine) lettuce complies with 'Metodyka doslidnoi spravy $\mathrm{v}$ ovochivnytstvi i bashtannytstvi' (The Rules of 
Procedure for Arranging Vegetable and Melon Growing Trials) [3] and 'Metodika polevogo opyta' (Rules of Procedure for Field Trial) [4]. The trials include phrenology observations and biometric examinations $[5,6]$. Analysis of the variance in a sample of 20 plants indicates leaf length and width, head height and diameter. The mean value $\left(\mathrm{n}_{\text {mean }}\right)$ and mean square deviation $(\sigma)$ have been found, which enables establishing the thresholds ( $\min -\max$ ) for the range of quantitative characteristic expressions, where $\mathrm{n}_{\text {mean }} \pm \sigma$ [7].

The study subject targets the workflow of vegetative and generative organs development with the view of implementing Lactuca sativa var. longifolia L. Romaine lettuce plants potential productivity in the course of growth and development thereof. The scope of the study covers the identification of 'Skarb' Romaine lettuce variety.

'Skarb'. The variety is of domestic breeding. Its development has engaged the author thereof. It is a mid-season cultivar (48 days from mass sporting to marketable maturity). The seed colouration is brown; the seedling displays no anthocyanin colouration. The attitude of elliptic, thick leaves (external) at harvesting maturity is erect. Leaf apex shape is obtuse. The leaves are dark green without any expression of anthocyanin colouration. The leaf upper side glossiness is moderate. Leaf blade blister is moderate, blisters are of average size. Undulation and lobbing of leaf blade margin are absent. Leaf blade venation pattern is not fan-like. Axil branching is absent. Seed stem is free of fasciation. The head is large by diameter, dense, narrow elliptic by longitudinal shape. The average weight of a head is $0.5 \mathrm{~kg}$.

The seed is ripening within 100 to 110 days. Marketable yield of heads is 32 tons per ha.

The ranges of leaf and head quantitative characteristics, numeric values of measurements and calculations have established the variation series. The latter are presented as a model diagram displaying the differing frequency values by columns of appropriate height.

In order to plot up the variation curve of the histogram, the relevant quantitative ranges of leaf length and head height have been processed mathematically.

Arithmetic mean value refers to the principal index of average quality of the items to be examined and is computed as follows:

$$
a=\frac{\sum_{i=1}^{n} a_{i}}{n} .
$$

Allocating the sample among the frequencies enables computing the arithmetic mean value with more convenient equation, where $n=20$, $k=5$, while the arithmetic mean:

$$
a=\left(a_{1} m_{1}+a_{2} m_{2}+\ldots+a_{k} m_{k}\right) / 20 .
$$

The other variable descriptive of the population is a mean square deviation. That index is of exceptional value for math statistics.

It applies as an absolute measure of diversity. Besides, it underpins nearly all characteristics of variability, distribution, correlation, regression, dispersion analyses, etc. The principal equation to compute the mean square deviation follows:

$$
\sigma=\sqrt{\frac{\sum\left(a_{i}-a\right)^{2}}{v}}=\sqrt{\frac{\sum\left(a_{i}-a\right)^{2}}{n-1}}
$$

(the sample is not grouped by frequencies),

$$
\sigma=\sqrt{\frac{\sum\left(a_{i}-a\right)^{2} m_{i}}{n-1}}
$$

\section{(grouped),}

where s (sigma) - mean square deviation (name of the symbol also attributes to the index itself, so that the mean square deviation is commonly referred to simply as 'stigma'); $\left(a_{i}-a\right)-$ mean (central) deviation, that is, the difference between each variance and the arithmetic mean; $v$ - number of degrees of freedom; the computations assume the number of degrees of freedom equals to the number of variances minus one, that is $v=n-1$.

The key advantage of mean square deviation is the complete quantitative characteristic of the variability of the index being examined. However, the index does not enable comparing the variability of two groups of different mean value of the characteristic being examined and the variability of different characteristics. To remedy the situation, one would apply the following variability index: the variability or variation ratio. The ratio of mean square deviation to arithmetic mean of the sample, expressed as a percentage, is a variation ratio.

$$
V=\frac{\sigma}{a} 100 \% .
$$

The variation ratio enables comparing the variability degree inherent in different characteristics. The higher is the ratio, the higher is the overall variability inherent in the characteristic. Low variability ratio $V=\leq 10 \%$ indicates general uniformity of a variety by that characteristics, whereas a high ratio would suggest a lack of uniformity.

The range of length quantitative values variability, i. e. the difference between the highest 
and the lowest value in the range of variables, is to be calculated. The finding is to be used for histogramming.

$R=a_{\max }-a_{\text {min }}$

where $\stackrel{R}{R}$ - range of variation

$a_{\text {max }}$ - maximum value of the sample

$a_{\text {min }}-$ minimum value of the sample.

Stability of each characteristic has been examined. Lewis Stability Factor applies for that purpose (S.F. $=\mathrm{X}_{\text {max }} / \mathrm{X}_{\text {min }}$ ). Its value varies from unity and on. The closer the factor approaches unity, the more stability the characteristic is acquiring.

Results and discussion. The morphological description method has been applied to identify vegetative and generative organs of Skarb Romaine lettuce variety plants. The biometric examinations are completed for the following characteristics: external leaf: by length, external leaf: by width, external leaf: number of leaves, head: diameter, head: height, head: weight: Table 1 displays the statistical data for the external leaf.

Table 1

Statistical data of variation series for internal leaf length

\begin{tabular}{|c|c|c|c|c|c|c|}
\hline$m_{i}$ & $\mathrm{a}_{\mathrm{j}}$ & $\mathrm{a}_{\mathrm{j}} \mathrm{m}_{\mathrm{j}}$ & $\left(\mathrm{a}_{\mathrm{j}}-\mathrm{a}\right)$ & $\left(\mathrm{a}_{\mathrm{j}}-\mathrm{a}\right) \cdot \mathrm{m}_{\mathrm{i}}$ & $\left(\mathrm{a}_{\mathrm{i}}-\mathrm{a}\right)^{2}$ & $\left(\mathrm{a}_{\mathrm{j}}-\mathrm{a}\right)^{2} \cdot \mathrm{m}_{\mathrm{i}}$ \\
\hline 3 & 18.5 & 55.5 & -0.98 & -2.94 & 0.96 & 2.88 \\
\hline 5 & 19.0 & 95.0 & -0.48 & -2.40 & 0.23 & 1.15 \\
\hline 5 & 19.5 & 97.5 & 0.02 & 0.10 & 0 & 0 \\
\hline 4 & 2.00 & 80.0 & 0.52 & 2.08 & 0.27 & 1.08 \\
\hline 3 & 20.5 & 61.5 & 1.02 & 3.06 & 1.04 & 3.12 \\
\hline \multicolumn{3}{|c|}{$\begin{array}{c}\text { Arithmetic } \\
\text { mean } \\
\text { a 19,48 }\end{array}$} & $\begin{array}{c}\text { The total of all } \\
\text { deviations = 0 or } \\
\text { very close to 0 }\end{array}$ & $\begin{array}{c}\sum_{i}\left(\mathrm{a}_{\mathrm{j}}-\mathrm{a}\right) \cdot \mathrm{m}_{\mathrm{i}}=8.23 \\
\end{array}$
\end{tabular}

Upper and lower limits have been found for each subgroup of equally measured values. The measured results get grouped, their frequency arrays with sub-group intervals and the number of measured results within those intervals, i.e. the frequency, provided.

\begin{tabular}{|l|c|c|c|c|c|}
\hline Interval & $18.5-$ & $18.9-$ & $19.3-$ & $19.7-$ & $20.1-$ \\
& 18.8 & 19.2 & 19.6 & 20.0 & 20.5 \\
\hline Frequency & 3 & 5 & 5 & 4 & 3 \\
\hline
\end{tabular}

This case resolves to $19.48 \pm 1.96 \times 0.15$, so that the confidence range is 19.19 to 19.77 . Ta- ble 2 indicates the findings as processed according to the Variation Series program.

In order to find the note of expression of 'External leaf: by length' as a relevant morphological characteristic the mean value $\mathrm{a}=19.48$ and the mean square deviation $\mathrm{s}= \pm 0.65$ are to apply. It is the $a \pm \mathrm{s}$ that would enable finding the thresholds for min and max of the ear length quantitative values, with follow-up determination of relevant characteristic note of expression. That is to say, the note and state of expression thereof are subject to compulsory assessment as the uniformity is examined. The relevant computations workflow would look as follows:

$a_{\min }=19.48-0.65=18.83 \mathrm{~cm}$
$a^{2}=19.48+0.65=20.13 \mathrm{~cm}$.

$a_{\text {max }}=19.48+0.65=20.13 \mathrm{~cm}$.

The length of a standard internal leaf of the Romaine lettuce is ranging within 18.83 to $20.13 \mathrm{~cm}$. The quantitative variables of the Romaine lettuce internal leaves length have resulted in rather high values of the characteristic expression. The general sample of the characteristics to be examined includes 60 plants of Skarb Romaine lettuce variety. 25 plants have been marked to analyze the variation. These are their measured values that actually set up the variation series for relevant characteristics of the external and internal leaves and the head (Fig. 1).

The trial includes biometric examinations of five morphological traits and two VCU characteristics. The input data enters seven variation series, each containing 25 items of data. Searching for the thresholds has returned notes of expression for the leaf and the head QN-characteristics (Table 3).

Finding the thresholds of quantitative characteristics of leaf and head and identifying the note of characteristic expression are outlined below in relevant succession:

$$
\begin{aligned}
& \text { Leaf width: } \\
& a \underset{\min }{=}=7.84-1.24=6.6 \mathrm{~cm} ; a_{\max }=7.84+ \\
& 1.24=9.1 \mathrm{~cm} \text {. }
\end{aligned}
$$

The numerical values of leaf width range within 6.6 to $9.1 \mathrm{~cm}$. The expression thus meets the note of 7 (large). Lewis Stability Factor is as follows: S.F. $=1.4$.

Searching up the thresholds for internal leaf length of Romaine lettuce applying the Variation Series program

\begin{tabular}{|c|c|c|c|c|c|}
\hline Mean value & Dispersion & $\begin{array}{c}\text { Mean square } \\
\text { deviation }\end{array}$ & Error of mean & $\begin{array}{c}\text { Variation } \\
\text { ratio }\end{array}$ & Accuracy \\
\hline$a=19.48$ & $D=0.42$ & $\mathrm{~s}= \pm 0.65$ & $\Delta=\mathrm{m}_{\mathrm{a}} \approx \pm 0,15$ & $V=3.4 \%$ & $m_{V}=\frac{\Delta}{a}=0,8$ \\
\hline
\end{tabular}

*The table-derived t-criteria at the level of significance of $5 \%$ for all the var. row $=2.1$. 
Leaf length:

$a_{\min }=25.89-4.91=20.91 \mathrm{~cm}$;

$a_{\max }=25.89+4.91=30.80 \mathrm{~cm}$.

The numerical values of leaf length range within 20.91 to $30.80 \mathrm{~cm}$. The expression thus meets the note of 7 (large). The characteristic stability: S.F. = 1.5.

Number of leaves:

$a_{\min }=27.04-2.11=24.93 \mathrm{pcs}$;

$a_{\max }=27.04+2.11=29.15$ pcs.

The number of leaves shaping the head range within 24 to 29 pcs. Note of expression is 7 (large). The characteristic is relatively stable: S.F. $=1.2$.

$$
\begin{aligned}
& \text { Head diameter: } \\
& a_{\min }=17.21-1.30=15.91 \mathrm{~cm} ; \\
& a_{\max }=17.21+1.30=18.51 \mathrm{~cm} .
\end{aligned}
$$

The numerical values of leaf diameter range within 15.91 to $18.51 \mathrm{~cm}$. The expression thus meets the note of 9 (very big). The characteristic stability: $\mathrm{S} . \mathrm{F}$. $=\mathbf{1 . 1}$.

\section{Head height:}

$a_{\min }=26.86-2.00=24.86 \mathrm{~cm}$;

$a_{\max }^{\min }=26.86+2.00=28.86 \mathrm{~cm}$.

Such thresholds have returned 7 (large) as a note for characteristic expression. The quantitative characteristic stability: S.F. $=1.1$.

The techniques of variance analyses have had a particular application aimed at VCU characteristics: weight of head and yield of Skarb variety.

Head weight:

$a_{\text {min }}=409.00-89.88=319.12 \mathrm{~g}$;

$a_{\max }^{\min }=409+89.88=498.88 \mathrm{~g}$.

The head weight thresholds of 319 to 499 $\mathrm{g}$ have returned 5 as a note of expression (medium). The index numerical value wide range of variation causes instability of the head weight quantitative characteristic: S.F. $=1.6$.

The yield of marketable products of the lettuce range within

$$
a_{\min }=28.81-2.29=26.52 \mathrm{mt} \text { per ha; }
$$$$
a_{\max }=28.81+2.29=31.10 \mathrm{mt} \text { per ha. }
$$

The yield ranging within 26.52 to $31.10 \mathrm{mt}$ per ha secures the stability of essential VCU characteristic expression as certified by the S.F. $=1.2$. Stability of each characteristic is examined. The Lewis Stability Factor (S.F. $=\mathrm{X}_{\max } / \mathrm{X}_{\min }$ ) acquires its specific values for each characteristic. Its value amounting to $\geq 1$ is to be noted. The closer the S.F. value is approaching unity, the more stable the relevant characteristic is becoming, its expression flattening. The expression of such characteristics as the number of leaves, diameter and height of the head, the yield is quite stable (the S.F. value is closest to unity).

Conclusions. The Romaine lettuce internal leaves length secures the note of 5 (medium) assigned to the characteristic expression. The relevant thresholds range within 18.83 to $20.13 \mathrm{~cm}$, which is 2.08 to $10.86 \mathrm{~cm}$ less than the length of external leaves. The thresholds of external leaves length range within 6.6 to $9.1 \mathrm{~cm}$ meeting the note of 5 . The head characteristic of the leaves number, its thresholds ranging within 24.93 to 29.15 pcs, proves to be stable. Skarb Romaine lettuce variety is found to have a medium diameter of the head (15.90 to $18.51 \mathrm{~cm})$. The height of Romaine lettuce variety varies within the range of 24.86 to $28.86 \mathrm{~cm}$. That secures the stability $\mathrm{S} . \mathrm{F}=1.1$ of the characteristic expression. The VCU index of head value is quite stable, S.F.= 1.6, with minimum and maximum values equal to $319 \mathrm{~g}$ and $488 \mathrm{~g}$, respectively. The threshold values of Skarb Romaine lettuce variety yield (26.5 to $31.1 \mathrm{mt}$ per ha) secure the value of $\mathrm{S} . \mathrm{F}=1.2$.

\section{Bibliography}

1. Статистичний збірник. Сільське господарство України в 2005 р. - К. : Державний комітет статистики України, 2006. - 366 с.

2. Позняк 0. В. Деякі аспекти сучасної концепції щодо різновидностей виду Lactuca sativa L. / O. В. Позняк // Сучасні аспекти ведення сільського господарства : матеріали III Наук.-практ. конф. молодих вчених (17 лютого 2009 р., Прогрес). - Чернігів: Підрозділ операт. друку Чернігівського держ. ЦНТЕI, 2009. - С. 60-63.

Table 3

Findings resulted from statistical treatment aimed at detecting the thresholds of expression note for quantitative characteristics describing Skarb Romaine lettuce variety leaf and head

\begin{tabular}{|l|c|c|c|c|c|c|c|}
\hline \multicolumn{1}{|c|}{ Characteristic } & Mean & Error of mean & Dispersion & T.S.D. & Dev. ratio & Accuracy & t. \\
\hline Leaf: & & & & & & & \\
width, cm & 7.84 & 0.25 & 1.53 & 1.24 & 15.8 & 3.2 & 31.7 \\
length, cm & 25.89 & 0.98 & 24.09 & 4.91 & 19.0 & 3.8 & 26.4 \\
\hline Head: & & & & & & & \\
number of & & & & & & & \\
leaves, pcs & 27.04 & 0.42 & 4.46 & 2.11 & 7.8 & 1.6 & 64.0 \\
diameter, cm & 17.21 & 0.26 & 1.68 & 1.30 & 7.5 & 1.1 & 66.4 \\
height, cm & 26.86 & 0.49 & 4.00 & 2.00 & 7.4 & 1.5 & 67.2 \\
weight, g & 409.00 & 17.98 & 8079.25 & 89.88 & 22.00 & 4.4 & 22.8 \\
\hline Yield, mt per ha & 28.81 & 0.46 & 5.24 & 2.29 & 7.9 & 1.6 & 62.29 \\
\hline
\end{tabular}


3. Методика дослідної справи в овочівництві і баштанництві / за ред. Г. Л. Бондаренка, К. І. Яковенка. - Харків, 2001. - 370 с.

4. Доспехов Б. А. Методика полевого опыта (с основами статистической обработки результатов исследований) / Б.А.Доспехов. - 5-е изд., перераб. идоп.-М.: Агропромиздат, 1985. - 351 c.

5. Зайцев Г. Н. Математическая статистика в экспериментальной ботанике / Г. Н. Зайцев. - М. : Наука, 1984. - 423с.

6. Лакин Г. Ф. Биометрия : учеб. пособие для биол. спец. вузов / Г. Ф. Лакин. - 4-е изд., перераб. и доп. - М. : Высш. шк., 1990. - 352 с.

7. Лещук Н.В. Методика проведення експертизи сортів салату посівного (Lactuca sativa L.) на відмінність, однорідність і стабільність / Н. В. Лещук // Охорона прав на сорти рослин : офіц. бюл. - К. : Алефа, 2007. - Вип. 3, Ч. 2. - С. 366-379.

8. Современные методы селекции овощных и бахчевых культур / под ред. Т. К. Горовой, К. И. Яковенко. - Харьков, 2001. - 644 С.

\section{References}

1. Statystychnyy zbirnyk. Silske hospodarstvo Ukrainy v 2005 roci [Statistical Digest] (2006). Kyiv: Derzhavnyi komitet statystyky Ukrainy [in Ukrainian].

2. Pozniak, 0. V. (2009). Deiaki aspekty suchasnoi kontseptsii shchodo riznovydnostei vydu Lactuca sativa L. [Some aspects of the modern concept dealing with the subvariety of species Lactuca sativa L.]. Suchasni aspekty vedennia silskoho hosp- odarstva: materialy III nauk.-prakt. konf. molodykh vchenykh [Modern aspects of farming: proceedings of the $3^{\text {rd }}$ Science-topractice conference of young scientists], 2009, 17 Febr., Prohres (pp. 60-63). Chernihiv: N.p. [in Ukrainian].

3. Bondarenko, H. L., \& Yakovenko, K. I. (2001). Metodyka doslidnoi spravy $v$ ovochivnytstvi i bashtannytstvi [Methods of testing in vegetable and melon cultivation]. Kharkiv: N.p. [in Ukrainian].

4. Dospekhov, B. A. (1985). Metodika polevogo opyta (s osnovami statisticheskoy obrabotki rezul'tatov issledovaniy) [Methods of field experiment (with the basics of statistical processing of research results)]. (5th ed., rev.). Moscow: Agropromizdat [in Russian].

5. Zaytsev, H. N. (1984). Matematycheskaya statystyka $v$ eksperymentalnoy botanike [Mathematical statistic]. Moscow: Nauka [in Russian].

6. Lakin, H. F. (1990). Biometriya [Biometry] (4th ed., rev.). Moscow: Vysshaya shkola [in Russian].

7. Leschuk, N. V. (2007). Metodyka provedennia ekspertyzy sortiv salatu posivnoho (Lactuca sativa L.) na vidminnist, odnoridnist i stabilnist [Procedure of cutting lettuce varieties examination]. Okhorona prav na sorty roslyn [Protection of plant varieties rights], 3(2), 366-379 [in Ukrainian].

8. Horovoy, T. K., \& Yakovenko, K. I. Sovremennye metody selektsii ovoshchnykh i bakhchevykh kultur [Modern methods of vegetable and melon and gourds breeding]. Kharkov: N.p. [in Ukrainian].

УДК 635.522: 631.526 .32

Н. В. Лещук. Застосування варіаційної статистики для встановлення стабільності морфологічних та господарсько-цінних характеристик сорту Lactuca sativa var. longifolia L. 'Скарб'

Мета. Науково обґрунтувати практичне застосування елементів варіаційної статистики для визначення параметрів морфологічних та господарсько-цінних ознак сорту салату ромен. Методи. Польовий, лабораторний, аналітичний та статистичний. Результати. Ідентифіковано сорт салату ромен 'Скарб' за типом прояву кількісних (QN) ідентифікаційних ознак. Визначено та статистично опрацьовано результати господарсько-цінних характеристик сортів var. longifolia L. Розкрито практичне застосування гістограми та варіаційної кривої морфологічних ознак фенотипу під час тесту на однорідність. Виявлено кореляційний зв'язок кількісних ознак листка та головки салату ромен під час формування продуктивності рослин. Статистично підтверджено достовірність результатів показника врожайності салату ромен, встановлено граничні межі досліджуваних показників та визначено довірчі інтервали за роки досліджень. Висновки. Застосування коефіцієнта стабільності Левіса (S.F. $=X_{\max } / X_{\min }$ ) дало можливість встановити стабільність прояву кожної ознаки. Науково обґрунтовано практичне застосування гістограми та варіаційної кривої для визначення кодів прояву кількісних морфологічних ознак та параметрів господарсько-цінних характеристик сортів салату ромен 'Скарб”.

Ключові слова: салат ромен, сорт, ідентифікація, варіаційний ряд, відхилення, граничні межі, стабільність ознаки.

УДК 635.522: 631.526.32

Н. В. Лещук. Применение вариационной статистики для определения стабильности морфологических и хозяйственно-ценных характеристик сорта Lactuca sativa var. longifolia L. 'Скарб'

Цель. Научно обосновать практическое применение элементов вариационной статистики для определения параметров морфологических и хозяйственно-ценных признаков сорта салата ромэн 'Скарб'. Методы. Полевой, лабораторный, аналитический и статистический. Результаты. Идентифицирован сорт салата ромэн 'Скарб' по типу проявления количественных (QN) идентификационных признаков. Определены и статистически обработаны результаты хозяйственно-ценных характеристик сортов var. longifolia L. Раскрыто практическое применение гистограммы и вариационной кривой морфологических признаков фенотипа салата во время теста на однородность. Показано корреляционная связь количественных признаков листа и кочана салата ромэн, при формировании продуктивности растений. Статистически подтверж- дена достоверность результатов показателя урожайности салата ромэн, установлены предельные границы исследуемых показателей и определены доверительные интервалы за годы исследований. Выводы. Применение коэффициента стабильности Левиса (S.F. $=X_{\text {max }} / X_{\min }$ ) позволило установить стабильность проявления каждого признака. Научно обоснованное практическое применение гистограммы и вариационной кривой для определения кодов проявления количественных морфологических признаков и параметров хозяйственно-ценных характеристик сорта салата ромэн 'Скарб'.

Ключевые слова: салат ромэн, сорт, идентификация, вариационный ряд, отклонение, предельные границы, стабильность признака.

Надійшла 23.10.2015 